\title{
Dynamics of labour force for human resource management: A local economy perspective in Bangladesh
}

\author{
Jayanta Kumar Basak ${ }^{1, ~ *, ~ S u b a n ~ K u m a r ~ C h o w d h u r y ~}{ }^{2}$, Masum Miah ${ }^{3}$ \\ ${ }^{1}$ Department of Environmental Science and Hazard Studies, Noakhali Science and Technology University, Noakhali, Bangladesh \\ ${ }^{2}$ Department of Natural Sciences, Daffodil International University, Dhaka, Bangladesh \\ ${ }^{3}$ Department of Business Administration, Noakhali Science and Technology University, Noakhali, Bangladesh
}

Email address:

basak.jkb@gmail.com (J. K. Basak), chowdhury.suban@gmail.com (S. K. Chowdhury), masum7cu@gmail.com (M. Miah)

\section{To cite this article:}

Jayanta Kumar Basak, Suban Kumar Chowdhury, Masum Miah. Dynamics of Labour Force for Human Resource Management: A Local Economy Perspective in Bangladesh. Journal of Human Resource Management. Special Issue: International Human Resource Management. Vol. 2, No. 6-1, 2014, pp. 1-11. doi: 10.11648/j.jhrm.s.2014020601.11

\begin{abstract}
The trends of creation of new employment is essential to understand for human resource management because of the activities, policies, and practices of any organization involved in obtaining, developing, utilizing, evaluating, maintaining, and retaining the appropriate number and skill mix of employees. Therefore, the study has sought to provide an understanding on the issues and options involved in the characteristics included in broad sector of employment and employed population by major occupation, level of education, and occupation by sector of employment, employment by industry, status in employment etc. Moreover, the current research has explored the changing pattern of labour market in different points of view for both male and female workers. To achieve the aims of the study, data from Labor Force Survey (LFS) conducted by the Bangladesh Bureau of Statistics (BBS) during the period of 1999 to 2010 have been used. The study showed that the rate of growth in unemployed population was higher than the employed population which might create an extra pressure in labour market. Moreover, it is also found that acute skill shortage is another particular concern which is affecting labour market. The main reason beyond not only the education levels of the workforce are low, but the education and vocational training are not maintained towards the markets needs. Therefore, creating productive employment opportunities will be imperative for sustained economic growth as well as to achieve optimal productivity and effectiveness.
\end{abstract}

Keywords: Labour Force, Human Resource Management, Employment, Labour Market

\section{Introduction}

One of the principal development challenges for Bangladesh is the creation of employment for new entrants into the labour force ${ }^{1}$ and a great many who are currently underemployed $^{2}$. The labour force is growing at almost twice than the rate of growth in population [1]. This relationship is likely to persist over the next two decades or longer [2]. Moreover, the decrease of growth in population is more than offset by the increased rates of participation. According to

\footnotetext{
${ }^{1}$ As persons aged 15 years and over, who are either employed or unemployed during the reference period of survey. It excludes disabled and retired persons, income recipients, full time housewives and students, beggars and other persons who is not paid or get profit at least one hour during the reference week.

${ }^{2}$ Who as involuntarily out of gainful employment during the period of 15 years and above but has been actively looking for a job or is willing to work but not looking for work because of illness or believe that no work is available.
}

Bangladesh Bureau of Statistics (2010), the labour force increased at 42.6 percent between 1991 and 2005 for the entire population, with an increase of 31.7 percent for male and 126.5 percent for female [3].

Labour market in Bangladesh constitutes of three types of market: formal, rural informal and urban informal [1]. A small portion of the total labour force, however, works under the formal labour market framework. Besides, there are a few published and unpublished works on the participation behavior of rural persons in self-employment activities due to micro-finance programs.

Moreover, changes in labour market conditions are very different across Bangladesh [4]. For instance, real incomes from wage employment have grown rapidly in Chittagong compared to slow declining in Barisal. These differences have been divided between in East and West parts of Bangladesh with labour markets in the East tending to 
outperform than those in the West. Interestingly, similar patterns are seen in the magnitude of poverty declines across these two geographical areas. Furthermore, the gradual changes in the overall characteristics of the labour force are starkly contrasted by changes in female employment over the years.

The World Economic Forum Report on Global Gender Gap (2011) ranked Bangladesh at $68^{\text {th }}$ according to its gender gap inde $x^{3}$. In 2005, the rate of labour force participation was 82 percent for males and 12 percent for females [5]. Again, labour force participation of women and their wage rates are substantially lower than that of men in Bangladesh, girls surpass boys in school enrollment, especially in secondary school [6]. Moreover, women hardly participate in different productive activities outside home due to some traditional social barriers [7] [8]. A number of studies have been conducted on women's activities during 80s [9], [10], [11], [12], [13], [14], [15]. These studies found that contribution of women to socio-economic development were not visible, perhaps due to a set of social norms that enabled men to dominate women [16]. In recent years, however, a large number of young girls are working in readymade garment [17].

Since 2000, for female, wage in employment increased considerably according to the increased level of education. This improvement has been resulted in higher productivity and long working hours for women. However, improvements in education and wages have been concentrated largely amongst richer women. Hence, the impact on poverty of these trends is likely to be small. Extending good quality in secondary education opportunities to poor rural households has the potential of improving labour market outcomes further for both male and female labour force [18]. Therefore, government of Bangladesh has taken different initiatives to increase the rate of participation of female in education where secondary stipend program is one of them. It is observed that participation of labour force increased by 4 percent and the likelihood of women, working in the formal sector increased by 3 percent from 1995 due to this programme [19].

A number of studies have been conducted on labour market in Bangladesh under different aspects [20], [21], [22], [23], [24]. It is suggestive that a number of factors are needed to be considered while fixing the minimum wage [23]. Furthermore, the gender differentiation has significant socioeconomic impacts in the export-oriented garment industry of Bangladesh [22]. In this circumstances, firstly, the paper has explored the trends in the labour market during the period of 1999-2000 to 2010 as well as the extent to which changes in the participation of labour market occurred. Moreover, the study has attempted to understand those factors that have

\footnotetext{
${ }^{3}$ The Index is a framework for capturing the magnitude and scope of genderbased disparities and tracking their progress. The Index benchmarks national gender gaps on economic, political, education- and health-based criteria, and provides country rankings that allow for effective comparisons across regions and income groups, and over time. It is designed to measure gender-based gaps in access to resources and opportunities in individual countries rather than the actual levels of the available resources and opportunities in those countries.
}

driven changes in labour market over time. In order to observe the changing pattern of labour participation, data from Labor Force Survey (LFS) conducted by the Bangladesh Bureau of Statistics (BBS) in 1999-2000 [25], 2002-2003 [26], 2005-2006 [27] and 2010 [28] have been used.

\section{Trends of Labour Force in Bangladesh}

\subsection{Size of Labour Force and Composition}

The growing gaps between the creation of employment and the required number for the new entrants into the labour force, besides those who are currently underemployed is one of the major challenges and the reasons for dispossession of labour market in Bangladesh. The rate of growth in labour force is lower than the growth of population which is not satisfactory. During the period of $1999-2000$ to 2010 , population of the country increased by 24.4 million (from 124.30 million in 1999-2000 to 148.70 million in 2010), whereas the total working age population ${ }^{4}$ raised by 21.4 million. Among the total working age, employed population ${ }^{5}$ increased only by 16 million which is counted 65.6 percent of the growing population and 74.8 percent of the working age population (Table 1). Almost 2 million people have been added to the total population compared to nearly 1.6 million job opportunity every year.

Moreover, the rate of growth in annual labour force for the mentioned period stood at 3.37 percent by applying annual compound rate of growth method ${ }^{6}$. It is noticeable that growth of female labour force was much higher than the rate of growth in male. The annual rate of growth for female was 7.31 percent compared to 2.06 percent for male. It is observed from the labour force data that rural rate of growth was lower than the urban areas. The growth in rural labour force was only 3.27 percent against 3.76 percent for the urban area.

Besides this, there is a growing disparity between the rate of growth in employment and unemployment, implying fragility of absorption capacity and vulnerability of labourers to low-wage and non-adherence of rights. The annual compound rate of growth in employed population was lower than the unemployed population 7 . The rate of growth for employed population was 3.33 percent compared to 3.71 percent for unemployed people. Furthermore, the rates of

\footnotetext{
${ }^{4}$ As a person aged 15 years and over

${ }^{5}$ Is a person who was either working one or more hour hours for pay or profit or working without pay in a family farm or enterprise or organization during the reference period or found not working but had a job or business from which he/she was temporarily absent during the reference period.

${ }^{6}$ The compound rate of annual growth is calculated by taking the $n^{\text {th }}$ root of the total percentage growth rate, where $\mathrm{n}$ is the number of years in the period being considered. This can be written as follows:

CAGR $=\left(\frac{\text { Ending Value }}{\text { Beginning Value }}\right)^{\left(\frac{1}{\# \text { of years }}\right)}-1$

${ }^{7}$ Who as involuntarily out of gainful employment during the period of 15 years and above but has been actively looking for a job or was willing to work but not looking for work because of illness or believing that no work was available.
} 
growth for employed and unemployed population differed by the area and gender. The rate of growth for employed population was higher at urban area (3.61 percent) compared to the rural area (3.24 percent).

Table 1. Characteristics of population and labour force over the years (in million)

\begin{tabular}{|c|c|c|c|c|c|c|c|c|}
\hline \multirow{2}{*}{ Year } & \multicolumn{2}{|c|}{ Population } & \multicolumn{2}{|c|}{ Working age population } & \multicolumn{2}{|c|}{ Employed population } & \multicolumn{2}{|c|}{ Unemployed population } \\
\hline & Male & Female & Male & Female & Male & Female & Male & Female \\
\hline $1999-2000$ & 64.09 & 60.26 & 38.30 & 35.90 & 31.1 & 7.9 & 1.1 & 0.7 \\
\hline $2002-03$ & 68.33 & 65.08 & 41.20 & 39.60 & 34.5 & 9.8 & 1.5 & 0.5 \\
\hline $2005-06$ & 70.04 & 67.26 & 43.01 & 41.58 & 36.1 & 11.3 & 1.2 & 0.9 \\
\hline 2010 & 74.15 & 73.59 & 47.85 & 47.74 & 37.9 & 16.2 & 1.6 & 1.0 \\
\hline
\end{tabular}

Source: Labour Force Survey (LFS), 2010

The rate of labour force participation in Bangladesh remained relatively steady during the period of 1999-2000 to 2010. The absolute size of the labour force increased by 39.3 percent or approximately, 16 million people over the same period (Figure 1). However, rates of the participation differed by gender; only 21 percent female compared to 79 percent of male were active in the labour force in 1999-2000 and during 2010, it was 30.34 percent for female. Therefore, the rate of participation for female increased at a significant rate (102 percent) compared to male (only 39.3 percent). The rate of participation of female in labour force in 2002-03 and 200506 were 22.22 percent and 24.44 percent respectively.

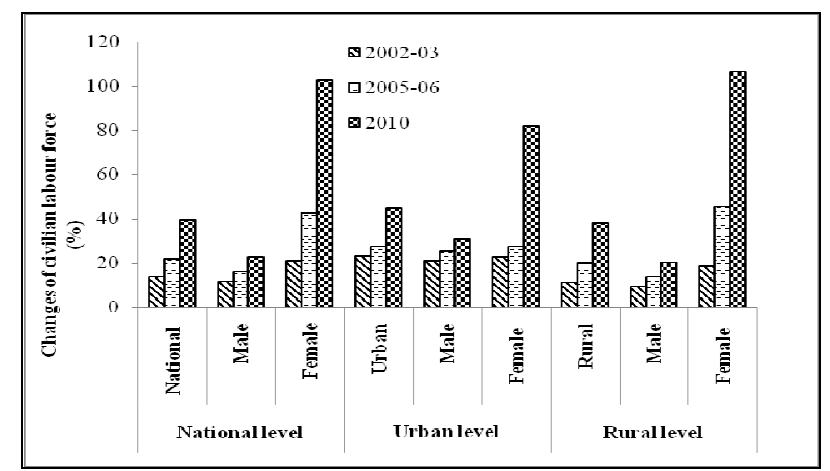

Figure 1. Changes in labour force (percentage) in Bangladesh compared to 1999-2000

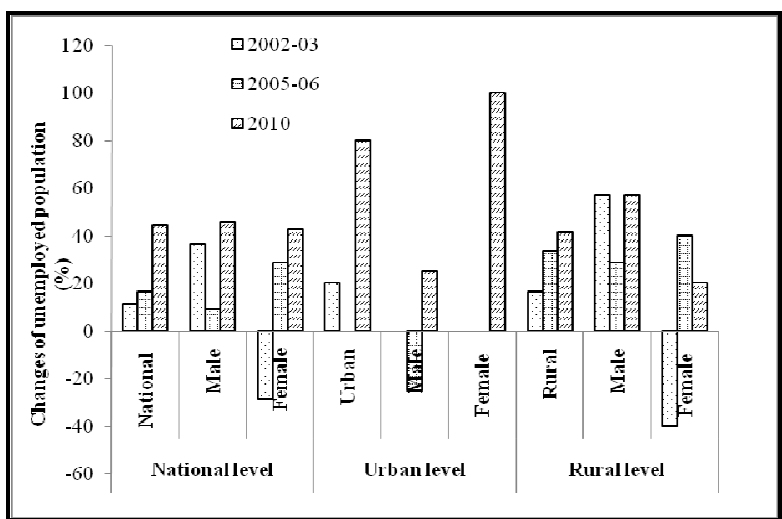

Figure 2. Changes in unemployed population (percentage) compared to 1999-2000

Moreover, the rate of participation also differed by area basis; more than three times (3.42 times) of labour force were active in rural areas compared to urban areas in 1999-2000. The rate, however, slightly decreased to 3.26 times in 2010 .
Labour force at urban area increased from 9.2 million in 1999-2000 to 13.3 million in 2010, which has been counted as 44.6 percent, whereas rural labour force increased 37.8 percent ( 31.5 million to 43.4 million) for the same period. It is indicated that migration of labour are playing a vital role, reflecting in the differences in rate of increase in labour force in rural and urban areas, resulting in skewed distribution of employment against the urban areas. There has been a continuous migration from rural areas to urban. Thus, the rural growth rate was observed lower than urban areas.

Furthermore, the participation tendency of female worker in labour market increased faster than male in both areas, reflecting the impressive underlying improvements in gender parity, with share of female population in total labour force of rural increasing from 6.4 million in 1999-2000 to 13.2 million in 2010 (or 106 percent). For urban areas, the participation tendency of female worker in labour market, however, raised from 2.2 million to 4 million (or 81.8 percent) for the mentioned period (Figure 1).

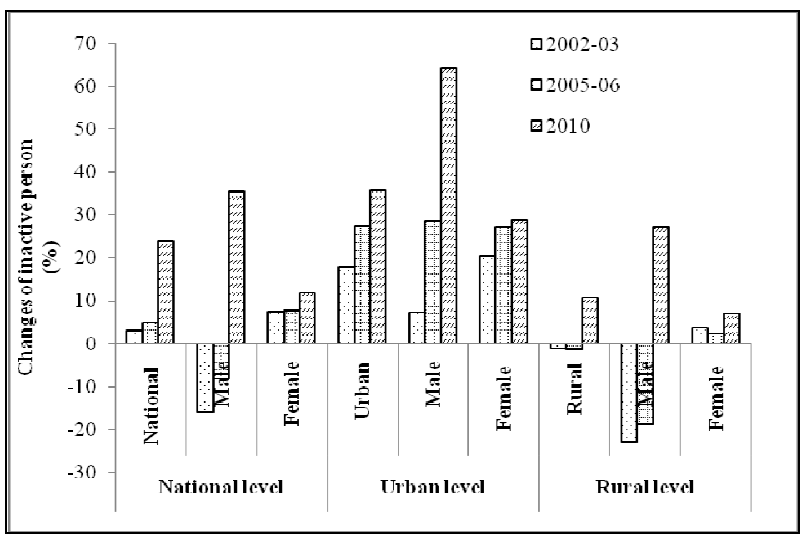

Figure 3. Changes in inactive person (percentage) in labour market compared to 1999-2000

In addition, the annual rate of growth of inactive person (not in labour force) ${ }^{8}$ for the mentioned period stood at 2.17 percent, lower than the rate of growth in labour force $(3.37$ percent). The annual compound rate of growth method found that growth of inactive male was much higher than rate of growth of female. The annual rate of growth for female was

\footnotetext{
${ }^{8}$ A person who is not engaged in an economic activity during the reference period of the survey. Regular full time students through engaged in household activities in leisure time are treated as inactive and remains outside the labour force. Household work also belongs to this category.
} 
only 1.14 percent compared to 3.05 percent for male. From the labour force data it is found that the rate of growth of inactive person in urban areas was much higher than rural areas (Figure 3). The rural growth of inactive person was only 1.05 percent against 3.12 percent for the urban areas.

\subsection{Unemployment Rate in Bangladesh}

The definition of 'Unemployment' is given by International Labour Organisation (ILO) and adopted by Bangladesh Bureau of Statistics (BBS) as "A person aged 15 years and over is considered as unemployed if he/she do not work at all during the preceding week of the survey (even an hour in the reference week) and is actively looking for work or is available for work but do not work due to temporary illness or because there is no work available”.

The rate of unemployment increased in Bangladesh during the 10 year-period (1999-2000 to 2010). According to Labour Force Survey, 2010 the rate of unemployment stood at 4.5 percent in 2010 which was 4.3 percent in 1999-2000. Furthermore, one of the most crucial findings is that the rate of unemployment for female has been decreasing; on the other hand, this rate has been increasing for male in the mentioned period; demonstrating increased propensity of profiteering by employers through maintenance of lower wages to women compared to men, women's compulsions for survival in the wake of declined support from family and rise of women-headed households. For the female, the rates of unemployment were 7.8 percent and 5.8 percent in 19992000 and 2010 respectively, whereas those were 3.4 percent and 4.1 percent for male for the corresponding years (Figure 4). Moreover, this rate was significantly higher in urban areas compared to rural areas in 2010. In rural areas, the rate of unemployment was only 4 percent, whereas at urban areas, it was 6.5 percent.

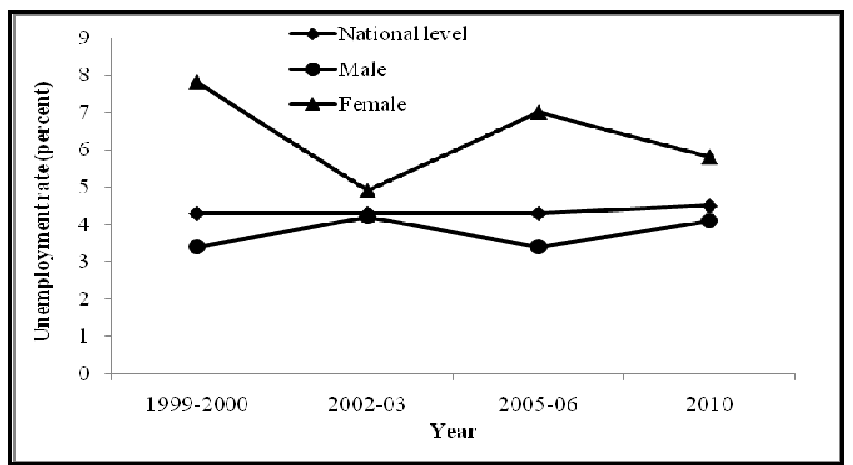

Figure 4. Changes in rate of unemployment in Bangladesh (year wise)

Table 2. Rate of unemployment (percent) by age group, sex and residence in 2010

\begin{tabular}{|c|c|c|c|c|c|c|c|c|c|}
\hline \multirow{2}{*}{ Age group } & \multicolumn{3}{|c|}{ Bangladesh } & \multicolumn{3}{|c|}{ Urban } & \multicolumn{3}{|l|}{ Rural } \\
\hline & Total & Male & Female & Total & Male & Female & Total & Male & Female \\
\hline Total & 4.50 & 4.10 & 5.70 & 6.50 & 5.70 & 8.30 & 4.00 & 3.60 & 4.90 \\
\hline $15-19$ & 10.6 & 9.80 & 11.4 & 12.4 & 11.7 & 13.4 & 10.1 & 9.80 & 10.6 \\
\hline $20-24$ & 7.10 & 6.80 & 7.70 & 9.90 & 8.70 & 11.5 & 6.30 & 6.20 & 6.40 \\
\hline $25-29$ & 5.40 & 4.30 & 7.30 & 7.90 & 6.30 & 10.8 & 4.60 & 3.70 & 6.20 \\
\hline $30-34$ & 4.20 & 3.80 & 4.80 & 5.60 & 5.00 & 6.90 & 3.60 & 3.40 & 4.00 \\
\hline
\end{tabular}

Source: Labour Force Survey (LFS), 2010

Table 3. Rate of unemployment (percent) by level of education in 2010

\begin{tabular}{|c|c|c|c|c|c|c|c|c|c|}
\hline \multirow{2}{*}{ Age group } & \multicolumn{3}{|c|}{ Bangladesh } & \multicolumn{3}{|l|}{ Urban } & \multicolumn{3}{|l|}{ Rural } \\
\hline & Total & Male & Female & Total & Male & Female & Total & Male & Female \\
\hline Total & 4.53 & 4.04 & 5.66 & 6.45 & 5.65 & 8.34 & 3.94 & 3.55 & 4.85 \\
\hline No education & 2.82 & 2.27 & 4.07 & 3.83 & 3.44 & 4.63 & 2.63 & 2.06 & 3.96 \\
\hline Class I-V & 3.79 & 3.39 & 4.73 & 5.06 & 4.42 & 6.41 & 3.53 & 3.09 & 4.18 \\
\hline Class VI- VIII & 5.18 & 4.80 & 5.98 & 5.62 & 5.08 & 6.88 & 4.57 & 4.69 & 5.68 \\
\hline Class IX-X & 7.16 & 6.76 & 7.88 & 9.11 & 7.44 & 12.40 & 6.50 & 6.53 & 6.84 \\
\hline HSC/equivalent & 13.74 & 11.83 & 19.52 & 17.04 & 13.89 & 25.40 & 11.35 & 10.42 & 14.56 \\
\hline Degree/equivalent & 0.50 & 0.35 & 1.25 & 0.43 & 0.38 & 0.61 & 0.59 & 0.31 & 2.02 \\
\hline Master's/equivalent & 10.25 & 8.23 & 19.87 & 11.48 & 9.24 & 20.01 & 8.56 & 6.97 & 19.39 \\
\hline Engineering/medical & 14.27 & 10.54 & 30.84 & 14.73 & 11.67 & 27.63 & 12.33 & 5.95 & 48.12 \\
\hline Technical/vocational & 0.00 & 0.00 & 0.00 & 0.00 & 0.00 & 0.00 & 0.00 & 0.00 & 0.00 \\
\hline Others & 2.93 & 0.00 & 9.73 & 0.00 & 0.00 & 0.00 & 3.93 & 0.00 & 23.35 \\
\hline
\end{tabular}

Source: Labour Force Survey (LFS), 2010

Moreover, the rates of unemployment differed by age of population; the highest unemployed has been found in the age group of 15-19 (10.6 percent) followed by age group of 20-24 (7.1 percent) and 25-29 (5.4 percent). The pattern also followed in case of the male and female. In case of female, the highest rate has been observed in 15-19 (11.4 percent) followed by 20-24 percent (7.7 percent) and 25-29 (7.3 percent). It is notable that rate of unemployment was lower in all the age group in the rural areas compared to urban areas. The rate of unemployment of female in the urban areas was 
higher in all groups compared to the rural areas (Table 2).

Besides this, the rate of unemployment increased with the increase of educational level up to Higher Secondary Certificate (HSC) or equivalent levels. After that, this rate reduced for degree or equivalent levels and slightly reduced for Masters Degree and equivalent levels as well. The rate of unemployment for engineering and medical degree holders was higher than degree, Masters Degree or equivalent. According to Labour Force Survey (LFS) 2010, at the national level, the highest rate of unemployment has been observed for those educational level of engineering or medical (14.27 percent) followed by HSC or equivalent (13.74 percent) and Secondary School Certificate (SSC) or equivalent ( 7.73 percent) (Table 3 ).

There exists variation between male and female in terms of rate of unemployment by the level of education. In case of male, the highest rate of unemployment has been found at HSC or equivalent educational level (11.83 percent) followed by medical/engineering degree holder (10.54 percent) and those with Masters Degree ( 8.23 percent). On the other hand, in case of female, the highest rate of unemployment has been observed for medical/engineering degree (30.84 percent) followed by Masters or equivalent degree (19.87 percent) and HSC or equivalent (19.52 percent). Moreover, there exists urban-rural variation in the rate unemployment by level of education. In the urban area, the highest rate of unemployment has been found in case of those having HSC or equivalent level (17.04 percent) followed by engineering or medical degree holders (14.73 percent) and for Masters or equivalent level (11.48 percent). Again, in case of rural area, the highest rate of unemployment has been observed for those having medical or engineering degree (12.33 percent) followed by educational level HSC or equivalent level (11.35 percent) and for Masters or equivalent degree holders (8.56 percent).

\subsection{Changes in Rate of Crude and Refined Activity in Labour Force}

Rates of Crude ${ }^{9}$ and refined activity ${ }^{10}$ are the two important indicators to assess the changing pattern of labour market in Bangladesh. It is observed that both two indications at national level increased over the years (Figure 5). Rate of crude activity has increased by 6.2 percent from 31.9 percent in 1999-2000 to 38.1 percent in 2010. Similarly, refined rate of activity increased by 4.4 percent from 54.9 percent in 1999-2000 to 59.3 percent in 2010. This increasing trend brought a positive meaning for labour market in Bangladesh. The changing pattern however, has been fluctuating on the survey years according to gender and area.

The rates of crude activity for male and female in 2010 were 52.5 percent and 23.3 percent compared to 48.3 percent

\footnotetext{
${ }^{9}$ Rate of Crude is the ratio of economically active population to the total population expressed in percentage? In the other words, the crude activity rate represents the labour force as percent of total population.

${ }^{10}$ Refined activity is the ratio of the economically active population persons to the total population aged 15 years and over expressed in percentage. This is also called economic participation rate.
}

and 14.1 percent in 1999-2000 respectively. There exists urban-rural and gender variation in the rate of crude activity. It is found that changes in the rate of crude activity in rural area was higher than the urban areas and female was higher compared to male during that specific period (Figure 5). In the urban area, the rate of crude activity in 2010 was 39 percent whereas in 1999-2000, it was 33.8 percent (increased by 5.2 percent). On the other hand, in the rural area, the rate of crude activity was 37.8 percent in 2010 compared to 31.4 percent in 1999-2000 (increased by 6.4 percent). In the urban and rural areas, rates of crude activity for female were 23.6 percent and 23.3 percent in 2010, whereas those were 16.2 percent and 13.5 percent respectively in 1999-2000.

The refined rate of activity at the aggregate level increased for both sexes and for female in 2010 compared to 19992000. This refined rate, however, decreased for male in 2010 compared to 1999-2000. Rates of refined activity were 59.3 percent, 82.5 percent and 36 percent in 2010 for both sexes, male and female, whereas, those were 54.9 percent, 84 percent and 3.52 percent in 1999-2000 respectively (Figure $6)$.

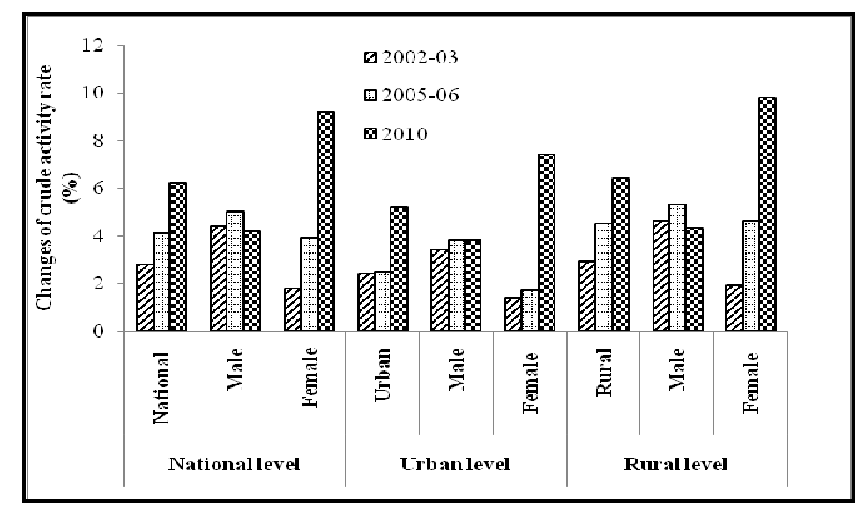

Figure 5. Changes in rate of crude activity in labour force compared to 1999-2000

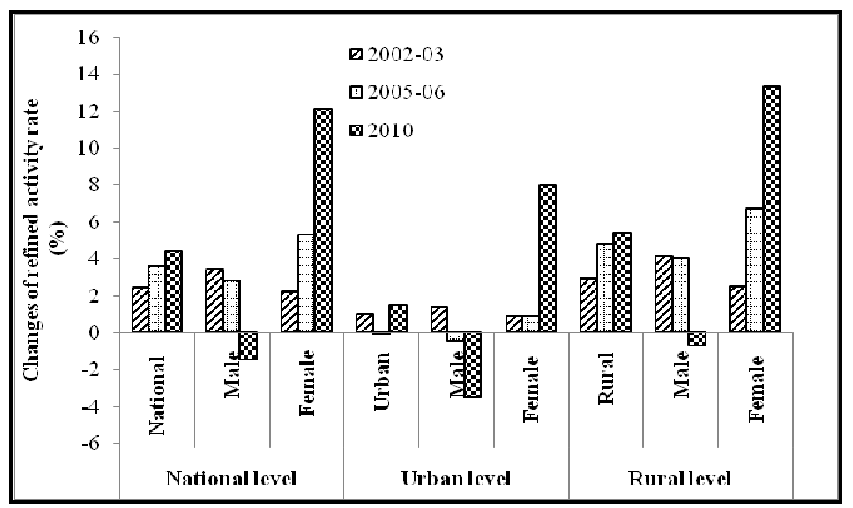

Figure 6. Changes in rate of refined activity in labour force compared to 1999-2000

\subsection{Rate of Participation in Youth Labour Force}

The annual rate of growth in youth labour force ${ }^{11}$ was higher than the rate of growth in total labour force during the

\footnotetext{
${ }^{11}$ Youth labour force is defined as labour force of age 15-29 years.
} 
period of 1999-2000 to 2010. The rate of growth in youth labour force for the mentioned period stood at 3.72 percent compared to the rate of growth in total labour force which was 3.37 percent per year. It is noticeable that growth of female was much higher than rate of growth of male in youth labour force. The annual rate of growth for female was 6.63 percent compared to 2.34 percent for male. According to the youth labour force data, rural rate of growth was lower than the urban areas. The rural growth in labour force was only 3.57 percent against 4.14 percent for the urban area.

Participation rates of youth labour force in Bangladesh remained relatively steady during the period of 1999-2000 to 2010. The absolute size of youth labour force has been increased by 44.1 percent (approximately 6.4 million people) over the same period (Figure 7). However, the rates of participation differed by gender; only 28.28 percent female compared to 71.72 percent male were active in youth labour force in 1999-2000 whereas this rate was 37.32 percent for female during 2010. Therefore, the rate of participation for female increased at a significant rate (90.2 percent) compared to male (only 26.0 percent).

Moreover, the rates of participation have also been differed according to area basis; more than three times (3.27 times) of youth labour force was active in the rural area compared to the urban areas in 1999-2000 which slightly decreased to 3.10 times in 2010. Youth labour force for urban area increased by 3.4 million in 1999-2000 to 5.1 million in 2010, which was 50 percent. On the other hand, rural labour force increased by 42.3 percent (from 11.1 million to 15.8 million) for the same period. Furthermore, the participation tendency of female worker in labour market increased faster than male in both areas, increasing from 3 million in 1999-2000 to 5.8 million in 2010 (or increased by 93.3 percent). For urban area, participation of female worker increased from 1.1 million to 2 million (81.8 percent) for the mentioned period (Figure 7).

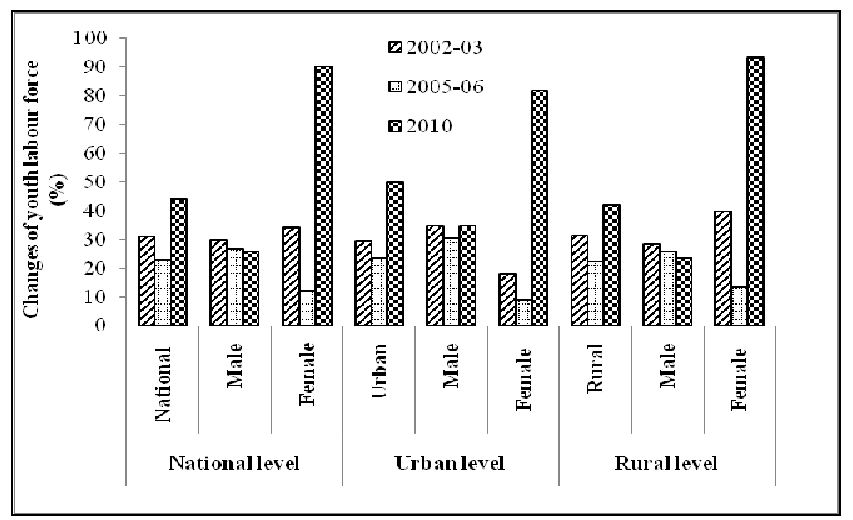

Figure 7. Changes in rate of participation in youth labour force compared to 1999-2000

Furthermore, from age-sex composition of youth labour force in 2010, the highest concentration of youth labour force has been seen in age group of 25-29 (36.99 percent) followed by age group of 20-24 (35.77 percent) and age group of 1519 (27.24 percent). Besides this, there exists sex variation in age composition of youth labour force. Among male, the percentage of youth labour force in age group of 15-19, was 27.98 percent against 26.01 percent for the female. Among the age group 20-24, percentage of male was 37.21 percent compared to 38.13 percent for female. For the age group of 25-29, the percentage of male labour force was 37.66 percent and female labour force was 35.85 percent. Moreover, the urban-rural variation in age composition is not very prominent. In the urban area, the percentage of total labour force in age group of 15-19, 20-24 and 25-29 were 27.72 percent, 36.44 percent and 34.84 percent respectively against 27.11 percent, 35.55 percent and 37.34 percent for the rural area respectively (Table 4).

Table 4. Economically active youths aged 15-29 years by age group, sex and area in 2010

\begin{tabular}{llllllllll}
\hline \multirow{2}{*}{ Age group } & Bangladesh & \multicolumn{3}{c}{ Urban } & \multicolumn{3}{c}{ Rural } \\
\cline { 2 - 11 } & Total & Male & Female & Total & Male & Female & Total & Male & Female \\
\hline $15-19$ & 27.24 & 27.98 & 26.01 & 27.72 & 26.25 & 29.97 & 27.11 & 28.51 & 24.66 \\
$20-24$ & 35.77 & 37.11 & 34.36 & 38.12 & 36.44 & 35.70 & 37.58 & 35.55 & 33.94 \\
$25-29$ & 36.99 & 37.66 & 35.85 & 35.84 & 38.05 & 32.44 & 37.39 & 37.54 & 37.02 \\
\hline
\end{tabular}

Source: Labour Force Survey (LFS), 2010

Table 5. Youth labour force aged 15-29 years by division (percent) in 2010

\begin{tabular}{|c|c|c|c|c|c|c|c|c|c|}
\hline \multirow{2}{*}{ Division } & \multicolumn{3}{|c|}{ Bangladesh } & \multicolumn{3}{|c|}{ Urban } & \multicolumn{3}{|l|}{ Rural } \\
\hline & Total & Male & Female & Total & Male & Female & Total & Male & Female \\
\hline Chittagong & 18.44 & 19.25 & 17.07 & 21.60 & 22.77 & 19.75 & 17.44 & 18.18 & 16.16 \\
\hline Dhaka & 32.25 & 31.38 & 33.71 & 49.95 & 48.40 & 52.34 & 26.61 & 26.17 & 27.34 \\
\hline Khulna & 11.16 & 11.06 & 11.33 & 8.34 & 8.37 & 8.31 & 12.05 & 11.88 & 12.36 \\
\hline Rajshahi & 26.51 & 26.34 & 26.80 & 14.52 & 14.46 & 14.61 & 30.33 & 29.98 & 30.96 \\
\hline Barisal & 5.47 & 5.53 & 5.37 & 2.71 & 2.77 & 2.62 & 6.36 & 6.37 & 6.32 \\
\hline Sylhet & 6.17 & 6.43 & 5.72 & 2.89 & 3.22 & 2.37 & 7.21 & 7.41 & 6.87 \\
\hline
\end{tabular}

Source: Labour Force Survey (LFS), 2010 
In addition, the highest percentage of labour force existed in Dhaka division (32.25 percent) followed by Rajshahi division (26.51 percent) and Chittagong division (18.44 percent) (Table 5). The distribution of male and female in youth labour force also followed the same pattern. Besides, in the urban area, the highest percentage of labour force was in Dhaka division (49.95 percent) followed by Chittagong division (21.60 percent) and Rajshahi division (14.52 percent). On the other hand, the highest labour force was in Rajshahi division (14.52 percent) for rural area followed by Dhaka (26.61 percent) and Chittagong division (17.44 percent) (Table 5).

Moreover, 51.5 percent of employed youth among the total youth labour force belonged to agriculture, forestry and fisheries followed by production and transport labourer (28.9 percent) and sales worker ( 9.7 percent) in 2010. According to the status of employment, the highest portion was unpaid worker (39.6 percent) followed by regular paid employee (17 percent) and self employed in non-agriculture (13.4 percent).

\subsection{Unpaid Family Worker in Labour Market}

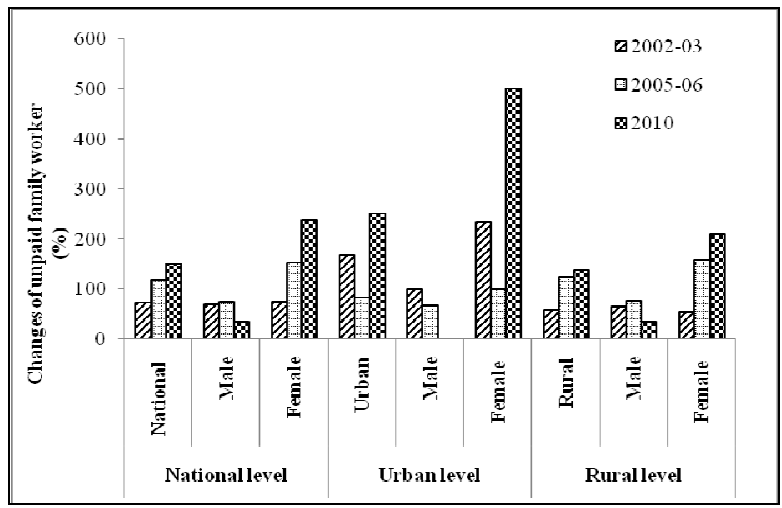

Figure 8. Changes in unpaid family worker compared to 1999-2000

Another alarming trend is that the number of unpaid family worker ${ }^{12}$ increased in a large volume over the years. The rate of growth of unpaid family worker was much higher compared to the rate of growth of total labour force during the period of 1999-2000 to 2010. Annual rate of growth for unpaid worker at national level was 9.64 percent, whereas the growth of total labour force during the same period was only 3.37 percent. In 2010, 11.8 million unpaid family workers were active in labour market, whereas only 4.7 million was involved in 1999-2000. Therefore, 7.1 million (increased by 151 percent) unpaid family workers have been added to the labour market during the same period (Figure 8). However, differed by gender in 1999-2000, 42.55 percent of them were male compared to 57.45 percent of female among the unpaid family worker. This portion was only 22.88 percent for male

\footnotetext{
${ }^{12}$ Unpaid family worker is a person who works at least one hour in the reference period (other than household work) without pay or profit in a family operated farm or in a business owned/operated by the household head or other members of the household to whom he/she is related by kinship, marriage, adoption or dependency.
}

and 77.12 percent for female during 2010. Therefore, unpaid female family worker increased at a significant rate (237 percent) compared to male (only 35.0 percent).

Moreover, number of unpaid family workers have also been differed by area basis where more than six times $(6.83$ times) unpaid workers worked in rural area compared to urban areas in 1999-2000 which decreased four times (4.62 times) in 2010. Furthermore, the number of unpaid female worker in labour market increased faster than male in both areas. The annual rates of growth of unpaid female work at urban and rural area were 6.17 percent and 6.81 percent respectively for the period of 1999-2000 to 2010 .

\subsection{Employment in Formal and Informal Sector}

Declined rate of growth has been observed for the formal sector at 3.40 percent per year during the period of 19992000 to 2010. On the other hand, informal sector showed a strong positive rate of growth (4.90 percent) for the same period. Consequently, significant number (1.8 million) of person joined in the informal sector in every year (Figure 9). Moreover, the rate of participation in formal and informal sector also differed by gender; male were engaged in informal sector more than 3 times (3.44 times) compared female in 1999-2000, whereas in 2010, this rate was slightly decreased at 2 times (2.17 times). On the other hand, 7 men were engaged in the formal sector against a single woman in 1999-2000, whereas this number was 4 in 2010. This is an indication that the engagement of female in both formal and informal sectors increased compared to male for the mentioned period.

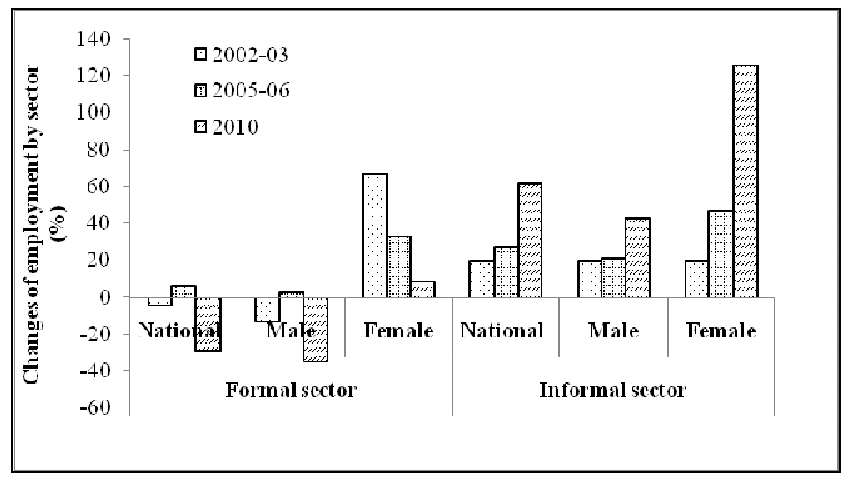

Figure 9. Changes in labour force in formal and informal sector compared to $1999-2000$

The total employed population was only 12.5 percent in formal sector and 87.5 percent in informal sector (LFS, 2010). Among the total population, 14.5 percent and 85.5 percent were male in the formal sector and informal sector respectively. For female, 7.7 percent and 92.3 percent were involved in the formal sector and informal sector respectively (Table 6). Moreover, there exists urban-rural variation in employment by formal and informal sector. In the urban area, 25.1 percent workers were involved in the informal sector compared to 7.7 percent in the rural area. On the other hand, in the urban area, 74.9 percent was involved in the informal 
sector compared to 91.3 percent in the rural area in 2010.

Table 6. Employed persons in formal and informal sector in 2010

\begin{tabular}{llllllllll}
\hline \multirow{2}{*}{ Sector } & \multicolumn{1}{l}{ Bangladesh } & \multicolumn{3}{c}{ Urban } & & \multicolumn{2}{c}{ Rural } \\
\cline { 2 - 10 } & Total & Male & Female & Total & Male & Female & Total & Male & Female \\
\hline Informal & 87.5 & 85.5 & 92.3 & 75.0 & 72.5 & 81.0 & 91.3 & 89.4 & 95.6 \\
Formal & 12.5 & 14.6 & 7.7 & 25.2 & 27.8 & 19.0 & 8.8 & 10.7 & 4.4 \\
\hline
\end{tabular}

Source: Labour Force Survey (LFS), 2010

\subsection{Employment by Broad Economic Sectors}

The sectoral share of generated wealth (measured in GDP) vis-à-vis number of people employed in that particular sector reveals an alarming account of disconnectedness between creation of wealth and absorption of employment, resulting in production and maintenance of poverty and inequality. Share of agricultural labour in broad economic has been declining day by day; the participation of agricultural labour in 2010 was 47.3 percent against 51.3 percent in 1999-2000. On the other hand, participation of non-agriculture (manufacturing, other industries and services) labour in broad economic sector was 52.7 percent and 48.7 percent in 2010 and 1999-2000 respectively. Therefore, share of agriculture labour reduced by 4 percent during this period (Figure 10).

Moreover, the engagement of female in agricultural sector remained as the highest position in broad economic sector (LFS 2010). Of the total employed person, 47.56 percent was engaged in agricultural sector followed by 35.35 percent in service sector and 17.52 percent in industrial sector. Besides this, for the male, the highest 41.11 percent was engaged in the service sector followed by agricultural (40.18 percent) and industrial (19.60 percent) sectors, whereas for female, the highest 68.84 percent was engaged in agricultural sector followed by service sector (21.89 percent) and industrial sector (13.32 percent) (Table 7).

Table 7. Employment by broad economic sectors in 2010

\begin{tabular}{llll}
\hline Broad Economic Sectors & Total & Male & Female \\
\hline Agriculture & 47.56 & 40.18 & 64.84 \\
Non-agriculture & 53.07 & 60.71 & 35.21 \\
Manufacturing & 12.44 & 12.73 & 11.77 \\
Other industry & 5.28 & 6.87 & 1.55 \\
Services & 35.35 & 41.11 & 21.89 \\
\hline
\end{tabular}

Source: Labour Force Survey (LFS), 2010

\subsection{Changes of Employment in Major Occupation of the Labour Market}

Employment in major occupation increased by 38.7 percent whereas total labour force in major occupation was 54.1 million in 2010 against 39 million in 1999-2000. Among all employed population, the highest 47.50 percent were engaged in the sectors of agriculture, forestry and fisheries (AFF) followed by 24.95 percent in production, transport labours and others (PTO), 15.16 percent in sales workers (SW), 5.55 percent in service workers (SER), 4.44 percent in professional and technical (PT,) 1.85 percent in clerical workers (CW) and only 1.3 percent in administrative and marginal sector (AM) in 2010. On the other hand, in 19992000, AFF also stood at the highest position (51.03 percent) followed by 20.77 percent in PTO, 14.87 percent in SW, 5.64 percent in SER, 4.10 percent in PT, 3.08 percent in CW and only 0.52 percent for AM sectors. However, the positive change of percentage in employment in major occupation were 29.1 percent for AFF, 66.7 percent for PTO, 41.4 percent for SW, 36.4 percent for SER, 50 percent for PT and a huge amount of change has been followed for AM (250 percent), whereas CW followed a negative change in 2010 compared to 1999-2000 (Figure 10).

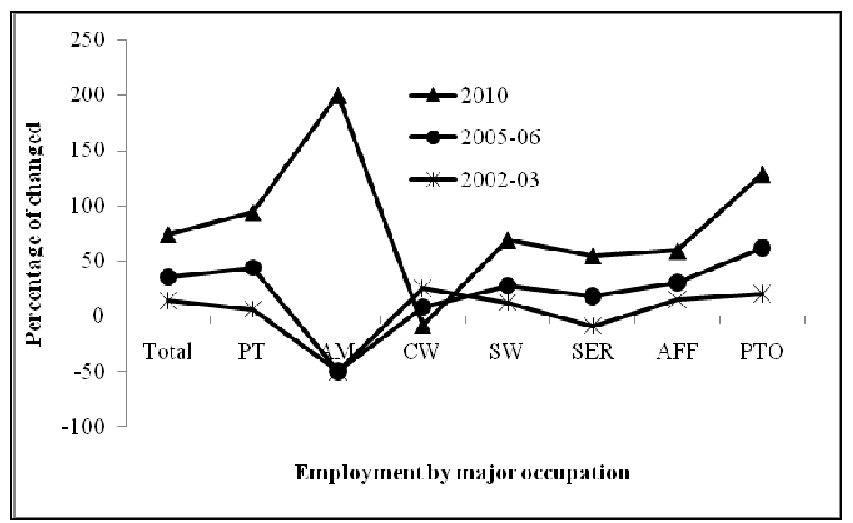

Figure 10. Changes in employment in the major occupation compared to 1999-2000

\subsection{Changes of Employment in Major Industry}

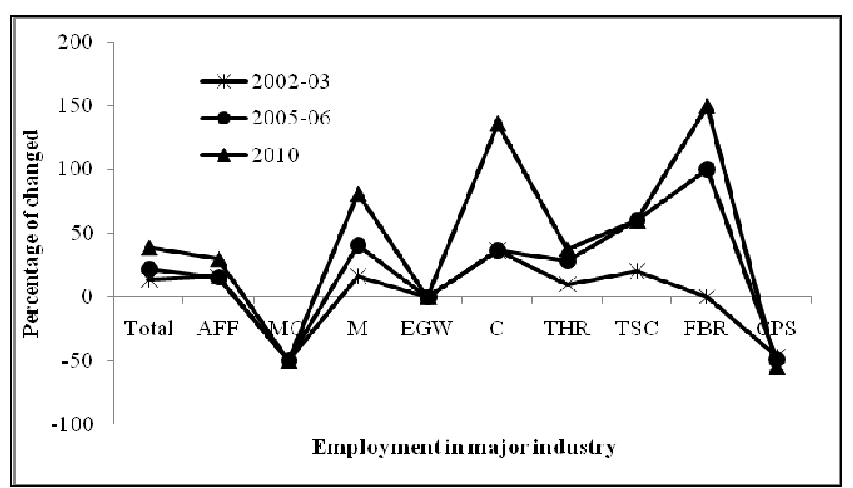

Figure 11. Changes in employment in the major industry compared to 1999 2000

(AFF: Agriculture, Forestry and Fisheries; MQ: Mining and quarrying; M: Manufacturing; EGW: Electricity, gas and water, C: Construction; THR: Trade, hotel and restaurant; TSC: Transport, storage and communication; CPS: Community and personal services) 
The highest change of employment has been observed in finance, business and real estate (increased by 150 percent) followed by construction (increased by 100 percent) and manufacturing (81.1 percent) industry in 2010 compared to 1999-2000 (Figure 11). At national level, the highest change of employment has been absorbed as 47.50 percent by the industry of agriculture, forestry and fisheries followed by trade, hotel and restaurant (15.53 percent); manufacturing (12.38 percent); health, education, public administration and defense (6.28 percent) and construction (4.80) in 2010. On the other hand, agriculture absorbed 50.77 percent employment in 1999-2000 followed by trade hotel and restaurant (15.64 percent); manufacturing (9.49 percent) and construction (2.82 percent).

\subsection{Changes of Employment Status}

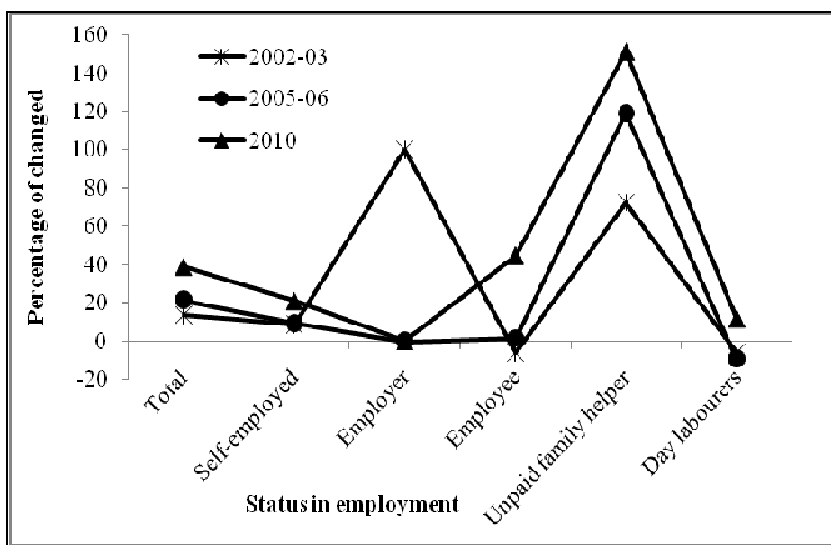

Figure 12. Changes in employment status compared to 1999-2000

Unpaid family helper increased significantly (151 percent) from 4.7 million in 1999-2000 to 11.8 million in 2010 followed by employee (44.6 percent), self-employed (20.9 percent) and day labourers (11.6 percent) (Figure 12). Among all the employment, the highest 40.67 percent have been included as self employed, 21.82 percent as unpaid family helper, 19.60 percent as day labourers and 17.4 percent as employee in 2010, whereas those percentages were 46.67, $12.05,24.36$ and 16.67 respectively in $1999-2000$ for the corresponding employment status.

\subsection{Changes in Labour Force in the Administrative Division}

In 2010, among the six administrative divisions, three divisions (Dhaka, Khulna and Rajshahi) showed increasing trend, whereas other three divisions (Chittagong, Barisal and Sylhet) showed decreasing trend of labour force compared to 2006. The highest positive change has been found for Rajshahi division which increased by 37.17 percent followed by Khulna (21.05 percent) and Dhaka (16.03 percent). On the other hand, negative change has been observed for Sylhet division which decreased by 8.33 percent, Barisal (5.71 percent) and Chittagong (2.06 percent). Moreover, the rate of participation for both male and female was the highest at Dhaka among the other five divisions for the both 2010 and
2006. The rates of participation of male and female in labour market at Dhaka were 31.9 percent and 32.4 percent respectively in 2010 which were 31.2 percent and 32.7 percent in 2006. The lowest rate of participation however, has been observed at Sylhet division. The rates of participation of male were only 6 percent and 7 percent for the total labour force in 2010 and 2006 respectively, whereas for female, those were 5.5 percent and 8.4 percent for the corresponding years.

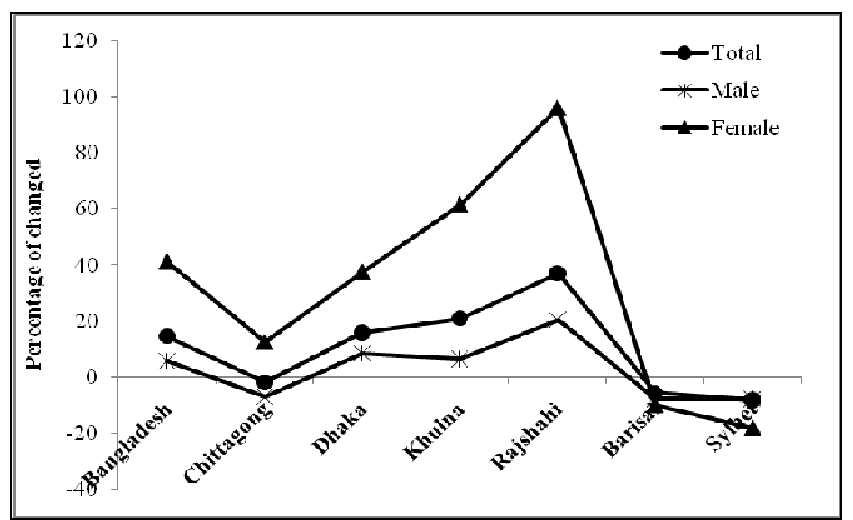

Figure 13. Participation of labour force in the administrative division (compared to 2006)

\section{Reasons Beyond the Facts}

Unemployment scenario in Bangladesh has been a serious problem, particularly for the educated youths. Lately, students are more prone to acquire science and business related educations, which are more transferable to the job. Despite that, those graduates are frustrated with the burden of education, as there are concurrent occurrences of joblessness. However, the prevalent dilemma of employability appears, as there are imbalances due to expected skills/qualifications by the ultimate employers. Therefore, helping to maintain performance standards and increase productivity through effective job design; providing adequate orientation, training and development; providing performance-related feedback; and ensuring effective two-way communication.

In particular, increases in opportunities for female wage employment have been associated with the increase of education level. Female education levels have increased at a faster rate than male education. Between 2000 and 2010 the average years of education for a female labour force participant has increased by over a year and therefore, the education gender gap has narrowed. Moreover, the NGO activities in rural areas have been expanded during this period significantly. Besides this, female garment workers evaluate their factory jobs in largely positive terms in labour force, including increased job satisfaction, new social networks, a greater voice in household decision-making, greater freedom from physical and verbal abuse, an enhanced sense of self-worth and self-reliance as well as greater personal freedom.

Moreover, there has been an increase in the proportion of the labour force engaged in salaried wage employment which 
is heavily concentrated in the non-farm sector and while selfemployment has remained stable over the period and consequently there has been a shift away from agriculture. Non-agricultural self-employment has increased, particularly for women, and this has been mostly a result of increased opportunities in sales and vending a trend which may be associated with an increase in access to micro-credit as well as rapid growth of RMG sector.

Besides this, the disparity between rural and urban job opportunity stands even after accounting for the cost of living differences, transportation and education facilities and wages. For example, urban wages for the agriculture are about 30 percent higher, while the wage gap in services varied between 22 percent (trade) to 65 percent (finance). These wage disparities in agriculture and other sectors seem to be driving the participation rate of workers in labour force in rural and urban in Bangladesh.

Furthermore, informalisation of the labour market with disproportionate growth in absorption people between formal and informal sectors, tilting in favour of the latter and the squeeze of the former. The formal sector witnessed a decline by 3.40 percent per year during the period of $1999-2000$ to 2010. On the other hand, informal sector has increased at an annual rate of 4.90 percent during the same period. The main reason beyond this factor is to all economic sectors experienced an increase in informal jobs. Many formal sector enterprises may give jobs that are closely with the informal sector. Besides, many employees in the RMG sector in Bangladesh do not get an appointment letter as well as many enterprises may not obtain the required registration etc. for qualifying as formal sector, because they do not have an incentive to do so.

Another alarming trend is rise in number of unpaid family workers and the growth rate of this category is much higher compared to the growth rate of total labour force during the period of 1999-2000 to 2010 and it was specially significant for female workers for both urban and rural area in Bangladesh. In terms of earnings, the paid female workers receive much less compared to their male counterparts. Sometimes, the daily average wage of male in rural areas is more than 80 percent higher than the average female wage and for urban areas, it is near about 45 percent. The main fact beyond this reason is to be a significant gender differences or gender inequity across all sectors and all categories of workers in the labour market.

\section{Conclusion}

The paper deals with the rate of labour participation and its trends in labour market over the 10 years (from 1999-2000 to 2010) in Bangladesh. These discussed issues are very important regarding its direct impact on human resource management of different government and non-government organizations in Bangladesh. Moreover, to create productive employment opportunities for a rapid growing labour force is clearly a major challenge for Bangladesh. Substantial labour force of 56.7 million, however, is growing at a rapid rate 3.37 percent per year or by adding almost 1.6 million workers each year. Generally, the growth in rapid labour force is considered to derive from two main sources: the demographic transition resulting in a surge of youthful entrants into labour market and the sharp increased in the participation of female labour force. However, the rate of growth in unemployed population was higher than the employed population which might create an extra pressure in the labour market. Despite the considerable pressure, labour market outcomes have been generally favourable. On the one hand, most of the new entrants between 1999-2000 and 2010 were able to find a job, keeping the rate of unemployment at about 4.5 percent. Again, the absolute size of the labour force has increased by 39.3 percent or approximately 16 million which reduced the rate of growth of inactive person over the same period. In addition, the annual rate of growth in the youth labour force increased and stood at 3.72 percent in 2010. At the same time, some important aspects of the labour market deserved closer attention. The rate of unemployment was 7.10 percent for the age of 20-24 years and even higher for those with the education of higher secondary or Masters and engineering or medical degree. The unpaid family workers have increased significantly. Furthermore, the formal sector comprised only about 12.5 percent of the total labour force and showed no signs of picking up- in fact, data for the period of 1999-2000 to 2010 found a relatively poor annual rate of growth in formal sector compared to the informal sector. Moreover, acute skill shortage is another particular concern which is affecting the labour market. Not only the education levels of the workforce are low, but the education and vocational training are not maintained towards the markets needs. On an average, the employed labour force has only 4 years of schooling. It is a major loss to productivity when even, this scarcity of human capital is not properly utilised. Furthermore, just over 1 percent of the labour force has had technical training or vocational education. Expectedly, labour market of Bangladesh is not expansive; almost half of the labour force is still in the agricultural sector. Moreover, there is a very little scope for the other sectors to provide job opportunity for the upcoming huge number of new entrants in the labour market. Therefore, rapid growth in labour force may present a critical development challenge for Bangladesh. In that situation, creating productive employment opportunities will be imperative for sustained economic growth as well as poverty reduction in Bangladesh. For that, more effective enforcement of existing labour market policies is needed. Furthermore, employment generation of the government should include sustained productivity and output growth across all major economic sectors; deeper and more focused government attention to enhancing worker skills, particularly by strengthening the higher education and making them more responsive towards market needs; improved urban management to facilitate rural-urban migration and continuous emphasis on gender empowerment to allow greater mobility of female workers to more productive employment opportunities. 


\section{Acknowledgement}

The Authors would like to thanks Rashed Al Mahmud Titumir, Mohammed Abdul Baten, and A. Z. M. Saleh of Unnayan Onneshan for valuable inputs during this study. A version of this research has earlier been published by the Unnayan Onneshan.

\section{References}

[1] R.A.M. Titumir, and J. Hossain, "Learning for Skill Formation and Employability: A Strategic Framework for Informal Sector in Bangladesh". Journal of the Institute of Bangladesh Studies, Bangladesh, vol. XXVI, 2003, pp 17-38.

[2] World Bank, World Development Report: Development and the next generation. Washington D.C: The World Bank, 2006.

[3] Bangladesh Bureau of Statistics (BBS). Statistical Yearbook of Bangladesh-2010. Dhaka, Bangladesh: Bangladesh Bureau of Statistics, 2010.

[4] S. Samarrai, "Changes in employment in Bangladesh, 20002005: The impacts on poverty and gender equity". A background paper for the Bangladesh Poverty Assessment (2007), South Asia Region, World Bank, 2006.

[5] World Bank, Poverty Assessment Report for Bangladesh: 2005. Washington D.C: The World Bank, 2007.

[6] World Bank, Poverty Assessment Report for Bangladesh: 2010. Washington D.C: The World Bank, 2012.

[7] M. Hossain, and A. Bayes, "Rural Economy and Livelihoods: Insights from Bangladesh". Dhaka, Bangladesh: A. H. Developing Publishing House, 2009.

[8] T.A. Abdullah, and S. Zeidenstein, "Village Women in Bangladesh: Prospects for Change”. UK: Oxford Press, 1982.

[9] K.A. Toufique, and C. Turton, "Hands not land: How livelihoods are changing in rural Bangladesh". Dhaka Bangladesh Institute of Development Studies (BIDS) and Department for International Development (DFID), 2002.

[10] R.M. Ahsan, S.R. Hussain, and J. Ben Wallace, "Role of Women in Agriculture. University of Dhaka", Dhaka: The Centre for Urban Studies, 1986.

[11] N. Chowdhury, "Revaluation of Women's Work in Bangladesh". The Bangladesh Journal of Agricultural Economics, vol.9, no.1, pp.8-15, 1986.

[12] A. Farouk, "The Hardworking Poor. Bureau of Economic Research", Dhaka: University of Dhaka, 1983.

[13] A.Halim, and F.E. McCarrthy, "Women Laborers in Rice Producing Villages of Bangladesh". Conference on Women in Rice Farming Systems, The International Rice Research Institute, Manila. Aldershot and Brookfield: Gower Publishing Company, 1985, pp. 242-254.

[14] K. Westergaard, "Pauperization and Rural Women in Bangladesh: A Case Study”, Comilla, Bangladesh: Bangladesh Academy for Rural Development (BARD), 1983.
[15] W.M.H. Jaim, and M.L. Rahman, "Participation of Women and Children in Agricultural Activities-A Micro Level Study in An Area of Bangladesh". The Bangladesh Journal of Agricultural Economics, Bureau of Socio-economic Research and Training, Bangladesh Agricultural University, Mymensingh, 1988, vol. XI,no.2, pp. 30-35.

[16] M.L.Bose, A. Ahmad, and M. Hossain, 2009, "The Role of Gender in Economic Activities with Special Reference to Women's Participation and Empowerment in Rural Bangladesh”. Gender, Technology and Development, 2009 vol.13, no. 1 .

[17] R. Heath, and A. M. Mobarak, "Does demand or supply constrain investments in education? Evidence from garment sector jobs in Bangladesh". Available at: http://faculty.som.yale.edu/mushfiqmobarak/garments.pdf [Accessed 20 December 2012]

[18] World Bank, Bangladesh Education Sector Review, vol. I, II and III, Dhaka: University Press Limited, 2000.

[19] M. Shamsuddin, "Labor Market Effects of Female Stipend Program in Bangladesh". Available at: http://www12.georgetown.edu/students/ms866/files/paper2.pd f. [Accessed 20 March 2013]

[20] Siddiqi, and G.A. Hafiz, "The Readymade Garment Industry of Bangladesh", Dhaka: The University Press Limited, 2004.

[21] R.I. Rahman, "Performance of Labor Market in Bangladesh: Recent Changes and Policy Implications", Dhaka, Bangladesh Bangladesh Institute of Development Studies, 2000.

[22] M. Hossain, and W.M.H. Jaim, "Empowering Women to Become Farmer Entrepreneur: Case Study of a NGO Supported Program in Bangladesh". Paper presented in Conference on New Directions for Smallholder Agriculture, Rome: IFAD Head Quarter, 2011.

[23] M. Asaduzzaman, "The next agricultural transition in Bangladesh: Which transition, why and how?" Conference on Understanding the Next Generation in Asia, 23 April, 2010 Bangkok.

[24] R.I. Rahman, "Skill Development in Bangladesh: Responses to Globalisation", Dhaka, Bangladesh: Bangladesh Institute of Development Studies, 2000.

[25] Bangladesh Bureau of Statistics (BBS), Report of the Labour Force Survey, Bangladesh-1999-2000. Dhaka, Bangladesh: Bangladesh Bureau of Statistics, 2002.

[26] Bangladesh Bureau of Statistics (BBS), Report on the Labour Force Survey, Bangladesh 2002-2003. Dhaka, Bangladesh: Bangladesh Bureau of Statistics, 2004.

[27] Bangladesh Bureau of Statistics (BBS), Report of the Labour Force Survey, Bangladesh 2005-2006. Dhaka, Bangladesh: Bangladesh Bureau of Statistics, 2008.

[28] Bangladesh Bureau of Statistics (BBS), Report of the Labour Force Survey, Bangladesh 2010. Dhaka, Bangladesh: Bangladesh Bureau of Statistics, 2011. 